Phylogeny of putative NTPases of picornavirus, comovirus and nepovirus. $a$, Phylogenetic scheme derived from the data of the table according to Brenner's hypothesis; $b$, phylogenetic tree generated by comparison of amino-acid sequences of evolutionary conserved segments of putative NTPases using a rateindependent distance matrix method $^{7,8}$. Only the branching order is shown; the branch

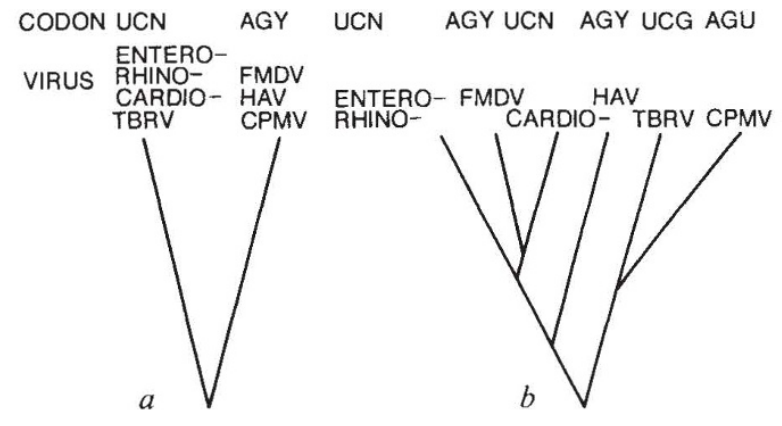
lengths were chosen arbitrarily. The branching order of this tree is identical to that generated for viral RNA polymerases ${ }^{9}$ and for capsid proteins ${ }^{10}$, and presumably reflects the phylogeny of viral genomes as a whole. Codon representations of serine in the GKS consensus are shown. Where, in a group of viruses, only one codon series is utilized, the branching order was not further specified.

codons occur without GKT intermediates.

In two other families of viral GKS/Tcontaining proteins serine is encoded almost exclusively by UCN, with AGY occurring only once (see table). Again, it is unreasonable to suppose that the potexvirus gene containing $\mathrm{AGU}$ originated from a separate line of descent. Both these families, however, include GKTcontaining proteins seemingly making the evolution of differentially encoded serines through threonine intermediates a possi-

\section{Serine codon representations in the nucleotide- binding motif of positive strand RNA viruses}

$\begin{array}{ccc}\text { Family of viral } & \begin{array}{c}\text { Consensus } \\ \text { sequence }\end{array} & \begin{array}{c}\text { Serine } \\ \text { (threonine) } \\ \text { codons }\end{array}\end{array}$

Family I

\begin{tabular}{lll}
$\begin{array}{l}\text { Alphaviruses } \\
\text { Coronavirus }\end{array}$ & GKS & UCN \\
Furovirus & GKS & UCC \\
Hordeivirus & GKS & UCN \\
$\begin{array}{l}\text { Tobravirus } \\
\text { Potexviruses }\end{array}$ & GKS & UCA \\
\multicolumn{1}{c}{ WC1MV p147 } & GKS & UCG \\
\multicolumn{1}{c}{ P26 } & GKS & UCU \\
\multicolumn{1}{c}{ p165 } & GKS & UCU \\
Tricornaviruses 26 & GKS & AGU \\
Tobamovirus & GKS & UCC \\
Tymovirus & GKT & ACN \\
Tymo & GKT & ACC \\
\end{tabular}

Family II

$\begin{array}{lll}\text { Enteroviruses } & \text { GKS } & \text { UCN } \\ \text { Rhinoviruses } & \text { GKS } & \text { UCN } \\ \text { Cardioviruses } & \text { GKS } & \text { UCN } \\ \begin{array}{l}\text { Aphtoviruses (FMDV) } \\ \text { Hepatitis A }\end{array} & \text { GKS } & \text { AGY } \\ \quad \text { virus (HAV) } & \text { GKS } & \text { AGY } \\ \begin{array}{l}\text { Comovirus (CPMV) } \\ \text { Nepovirus (TBRV) }\end{array} & \text { GKS } & \text { AGU } \\ \text { Family III } & \text { GKS } & \text { UCG } \\ & & \\ \text { Potyviruses } & & \\ \text { Flaviviruses } & \text { GKS } & \text { UCN } \\ \text { Pestivirus } & \text { GKT } & \text { ACN } \\ & \text { GKT } & \text { ACA }\end{array}$

For sources of sequence data see refs 4,11 and 12 . $\mathrm{N}$, any nucleotide; $\mathrm{Y}$, pyrimidine. The grouping of viral proteins containing the NTP-binding motif is according to refs. 4 and 12 . Potexviruses (as well as furoviruses and probably hordeiviruses) have two putative NTPases each ${ }^{4}$. Different species of enterovirus and rhinovirus, and different strains of foot and mouth disease virus (FMDV) and HAV have either $\mathrm{C}$ or $U$ in the third position; hence, $N$ or $Y$ is indicated, respectively. bility. Nevertheless, it seems that if this occurred then it did so only rarely.

Although our survey of serine codon usage in putative viral NTPases does not support Brenner's hypothesis, it exposes some intriguing variations in the evolutionary mechanisms of different phylogenetic lineages. At least two mechanisms may be invoked to explain how the UCN to AGY transition occurs without loss of serine at the enzyme active site. The first of these requires the simultaneous change of two adjacent bases. Given the high error rate of RNA replication ${ }^{6}$, this mechanism is more feasible for RNA viral genomes than for DNA genomes. An alternative mechanism involves the generation of a new serine codon next to the functionally important one (yielding a
GKSS sequence with the two serines encoded by codons of different series) followed by deletion of the original codon. This mechanism is equally feasible with DNA and RNA genomes and might operate wherever there is no strict constraint on the residue(s) next to the functional serine. Generally, understanding the evolutionary history of serine codons in catalytic centres of each enzyme class requires knowledge of its phylogeny derived from independent data.

EUGENE V. KOONIN

ALEXANDER E. GORBALENYA

\section{Institute of Poliomyelitis and}

Viral Encephalitides,

USSR Academy of Medical Sciences,

142782 Moscow Region,

USSR

1. Brenner, S. Nature 334, 528-530 (1988)

2. Henderson, G. et al. J. Bact. 169. 3778-3784 (1987)

3. Walker, J.E., Saraste, M.J., Runswick, M.J. \& Gay, N.J. EMBO J. 1, 945-951 (1982)

4. Gorbalenya, A.E., Blinov, V.M., Donchenko, A.P. \& Koonin, E.V. J. molec. Evol. 28 (in the press!

5. Evans, R.K., Haley, B.E. \& Roth. D.A. J. biol. Chem. 260, 7800-7804 (1985).

6. Steinhauer, D.A. \& Holland, J.J. A. Rev. Microbiol. 41, 409-433 (1988)

7. Yushmanov, S.V. \& Chumakov. K.M. Molek. Genetika 3, 9-15 (1988).

8. Chumakov, K.M. \& Yushmanov, S.V. Molec. biol. Evol. (in the press)

9. Koonin, E.V., Chumakov, K.M., Yushmanov, S.V. \& Gorbalenya. A.E. Molek. Genetika 3, 16-19 (1988).

10. Palmenberg, A.C. in Molecular Biology of Picornaviruses (ICN-UCl, in the press)

11. Gorbalenya. A.E., Koonin, E.V., Donchenko, A.P. \& Blinov, V.M. FEBS Lett. $23516-24$ (1988).

12. Gorbalenya, A.E., Koonin, E.V.. Donchenko, A.P. \& Blinov, V.M. (submitted).

\title{
Telomere formation in yeast
}

SIR-We recently demonstrated that during formation of new telomeres in the yeast Saccharomyces cerevisiae, telomeric sequences are often transferred between DNA termini'. We argued that the most reasonable explanation for this transfer is recombination between DNA termini. In a recent News and Views article ${ }^{2}$, however, Szostak suggested that the telomere resolution reaction ${ }^{3}$ (the cleavage between two blocks of telomeric sequences that are oriented as a head-tohead inverted repeat ${ }^{3.4}$ ) can provide an alternative explanation for our data, a possibility that can be addressed definitively by DNA sequencing. It is not clear to us why this possibility was raised because we stated' that our unpublished sequence data support the interpretation presented in the article; that is, the orientation of the transferred repeats is the same as that of the test termini (S.-S. Wang and V.A.Z., in preparation).

Although the sequence data eliminated the resolution model as an explanation for the telomeric transfer, we did not discuss these data specificially in terms of this model' $^{\prime}$. The resolution reaction never provided a likely explanation for our results because it requires three events: (1) circularization of linear plasmids bear- ing telomeric repeats at each end; (2) asymmetrical resolution of the circles thus formed; and (3) telomere formation on an end with the telomeric repeats in the 'wrong' ${ }^{\text {'.t }}$ orientation. Not only have none of these processes been demonstrated in yeast, but even symmetrical resolution is inefficient $(\sim 1 \text { per cent per cell division })^{+}$ compared with the sequence transfer we observe.

Because the resolution reaction is excluded unequivocally by DNA sequence data, telomere-telomere recombination remains the only reasonable explanation for the transfer of telomeric sequences that we have observed. Whether or not yeast exploits telomeretelomere recombination in the replication or maintenance of telomeres remains to be determined.

VIRGINIA A. ZAKIAN ANN F. PLUTA

Fred Hutchison Cancer Research Center, 1124 Columbia Street,

Seattle.

Washington 98104, USA

1. Pluta, A.F. \& Zakian. V.A. Nature 337, 429-433 (1989).

2. Szostak. J.W. Nature 337, 303-304 (1989).

3. Szostak. J.W. Cold Spring Harbor Symp quant. Biol. 47 1187-1194 (1982)

4. Murray, A.W., Claus, T.E. \& Szostak, J.W. Molec. cell. Biol 8. 4642-4650 (1988) 